\title{
New Record of Ciliates, Blepharisma undulans and B. steini (Ciliophora: Heterotrichida: Blepharismidae) from Korea
}

\author{
Eun Sun Lee and Mann Kyoon Shin* \\ Department of Biological Science, College of Natural Sciences, University of Ulsan, \\ Ulsan 680-749, Korea
}

\begin{abstract}
Two ciliate species of Blepharisma were collected from the riverine wetland and mountain peak soil in Korea, Blepharisma undulans Stein, 1867 and B. steini Kahl, 1932, which are reported for the first time from Korea. The description was based on the observations of live and protargol impregnation specimens. Diagnostics of these species (Blepharisma undulans vs. B. steini) are as follows. Body length/width ratio in vivo about $6 / 1$ vs. $2 / 1$, shaped in spindle vs. pyriform to ellipsoid and colored in pinkish vs. reddish. Macronuclei 2 vs. 1 , with 4-9 vs. 4-7 spherical micronuclei. Adoral zone of membranelles extends from anterior end to $1 / 3$ vs. $1 / 2$ 2/3 of body length, with 47-56 vs. 33-45 adoral membranelles. The numbers of somatic kineties are 22-27 vs. $18-22$.
\end{abstract}

Key words: Blepharisma, redescription, morphology, Ciliophora, Heterotrichida, Blepharismidae, Korea

\section{INTRODUCTION}

In 1849 , Perty defined that the genus Blepharisma has pyriform, spindle-form or ellipsoidal body, somewhat narrowing anteriorly, with dense ciliation, sharply curved peristome, and contractile vacuole as well as cytopyge in posterior part and color by pigments in subpellicular granules. The longitudinal ciliary rows lie in ridges and are variable in number depending upon the size of the organisms (Kudo, 1954; Bhandary, 1962; Hirshfield et al., 1965; Giese, 1973).

Some members of Blepharisma most easily mistaken for Spirostomum species which is rarely colored (never pink or red) and is contractile, has a collecting canal serving the contractile vacuole (Curds et al., 1983). Blepharisma has extensive variation because they are greatly affected by nutrition (size, shape, ciliary rows etc). Suzuki (1954) paid attention to the taxonomic confusion and proposed three subspecies of B. undulans : B. undulans undulans, B. undulans americanus and $B$. undulans japonicus mostly based on the nuclear behavior in division, as well as vegetative macronuclear configuration. After then, Bhandary (1962) elevated these three subspecies to species level and primarily emphasized the shape and size of macronucleus, body size, nuclear division, and conjugation.

The subgeneric groups of Blepharisma are based chiefly on the macronuclear configuration. Hirshfield et al. (1965)

*To whom correspondence should be addressed

Tel: 82-52-259-2396, Fax: 82-52-259-1694

E-mail: mkshin@ulsan.ac.kr suggested the four types of Blepharisma using the form of the interphase macronucleus: 1) compact, 2) filiform, 3) two or more nodes connected by a thin strand, and 4) two nodes connected by a thick strand or dumb-bell shaped. In addition, Giese (1973) also proposed four subgroups based on the forms of macronucleus: 1) compact, 2) filiform, 3) bimodal and 4) multimodal types. The status of the Blepharismidae and the subgeneric classification of Blepharisma based on nuclear configuration are not supported by the ontogenetic data available (Aescht and Foissner, 1998; Lynn, 2008).

More than 30 species of the genus Blepharisma have been reported from fresh, blackish and sea water as well as from the soil of many parts of the world (Hirshfield et al., 1965; Isquith et al., 1965; Dragesco, 1970; Giese, 1973; Dragesco and Dragesco-Kernéis, 1986; Al-Rasheid, 2001). In Korea, there are some records about the species of Blepharisma by some biological studies but no taxonomical records on this genus to confirm the reality of them.

The aim of the present work is to redescribe Blepharisma undulans and B. steini new to Korea.

\section{MATERIALS AND METHODS}

The specimens of Blepharisma undulans were collected from the rotting vegetation of freshwater in riverine wetland, Geumsa-myeon, Yeoju-gun, Gyeonggi-do (E $127^{\circ} 31^{\prime} 44^{\prime \prime} \mathrm{N} 37^{\circ}$ $25^{\prime 2} 3^{\prime \prime}$ ), on 8 January 2008. The specimens of B. steini were collected from the soil contained dry fallen leaves in the peak 


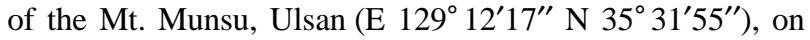
17 May 2008. The raw cultures of soil samples were established at room temperature in laboratory using non-flooded petri dish method (Foissner, 1992a).

Living specimens were isolated and examined under the bright field and differential interference contrast microscopes $(\times 50-1,000)$. The living and silver impregnated specimens were prepared by modified protargol and dry staining methods (Wilbert, 1975; Foissner, 1992b; Shin and Kim, 1993). Terminology and taxonomic scheme mostly follow Lynn (2008). Abbreviations are as follows. AZM : adoral zone of membranelles, AMs : adoral membranelles, CV : Contractile vacuole, $\mathrm{Ma}$ : macronucleus, $\mathrm{Mi}$ : micronucleus, $\mathrm{OG}$ : oral groove, PM : paroral membrane, PMA : anterior portion of paroral membrane, PMP : posterior portion of paroral membrane, SKs : somatic kineties.

\section{RESULTS AND DISCUSSION}

Family Blepharismidae Jankowski in Small \& Lynn, 1985 Genus Blepharisma Perty, 1849

\section{Blepharisma undulans Stein, 1867}

(Figs. 1, 2 and Table 1)

Blepharisma undulans Stein, 1867, p. 186; Kahl, 1932, p. 444; Suzuki, 1954, p. 206; Bhandary, 1962, p. 437; Lüftenegger et al., 1985, p. 575.

Description. Body shape spindle or bat-shaped, flattened laterally when not stuffed with food and very flexible but non-contractile; size 150-250 × 27.5-45 $\mu \mathrm{m}$ (average 203.8 $\times 34.2 \mu \mathrm{m}$ ) in vivo, length/width ratio about 6/1 (Fig. 1A-D). Cytoplasm colorless, while body surface colored pale pink due to subpellicular or cortical granules. Subpellicular granules having two patterns; 1) 4-5 rows pinkish subpellicular

Table 1. Morphometric data of Blepharisma steini (Bs) and B. undulans (Bu)

\begin{tabular}{|c|c|c|c|c|c|c|c|c|c|c|}
\hline Characters & Method & Species & Mean & Min. & Max. & Med. & SD & SE & Cv (\%) & $n$ \\
\hline \multirow[t]{4}{*}{ Body length } & $\mathrm{L}$ & Bs & 87.4 & 68.0 & 120.0 & 85.0 & 15.4 & 3.7 & 17.6 & 17 \\
\hline & $\mathrm{L}$ & $\mathrm{Bu}$ & 203.8 & 150.0 & 250.0 & 203.8 & 28.2 & 7.1 & 13.9 & 16 \\
\hline & $\mathrm{S}$ & Bs & 88.1 & 73.0 & 101.0 & 88.0 & 8.0 & 2.5 & 9.1 & 10 \\
\hline & $\mathrm{S}$ & $\mathrm{Bu}$ & 155.4 & 83.0 & 245.0 & 170.0 & 47.1 & 10.5 & 30.3 & 20 \\
\hline \multirow[t]{4}{*}{ Body width } & $\mathrm{L}$ & Bs & 41.8 & 35.0 & 50.0 & 40.0 & 4.7 & 1.2 & 11.3 & 15 \\
\hline & $\mathrm{L}$ & $\mathrm{Bu}$ & 34.2 & 27.5 & 45.0 & 33.8 & 3.4 & 0.9 & 10.0 & 16 \\
\hline & $\mathrm{S}$ & Bs & 56.8 & 41.5 & 68.0 & 58.5 & 7.9 & 2.5 & 13.9 & 10 \\
\hline & $\mathrm{S}$ & $\mathrm{Bu}$ & 66.4 & 26.0 & 94.0 & 62.8 & 18.1 & 3.9 & 27.2 & 22 \\
\hline \multirow[t]{4}{*}{ AZM length } & $L$ & Bs & 57.5 & 50.0 & 75.0 & 55.0 & 8.4 & 2.4 & 14.5 & 12 \\
\hline & $\mathrm{L}$ & $\mathrm{Bu}$ & 71.1 & 57.5 & 92.5 & 75.0 & 8.4 & 2.2 & 11.7 & 15 \\
\hline & $\mathrm{S}$ & Bs & 51.1 & 32.0 & 65.0 & 55.0 & 9.3 & 2.9 & 18.1 & 10 \\
\hline & $\mathrm{S}$ & $\mathrm{Bu}$ & 81.5 & 61.0 & 100.0 & 80.0 & 10.0 & 2.1 & 12.3 & 23 \\
\hline \multirow[t]{2}{*}{ AMs number } & $\mathrm{S}$ & Bs & 38.9 & 33.0 & 45.0 & 39.0 & 3.5 & 0.9 & 9.0 & 15 \\
\hline & $\mathrm{S}$ & $\mathrm{Bu}$ & 51.2 & 47.0 & 56.0 & 50.5 & 2.6 & 0.6 & 5.0 & 16 \\
\hline \multirow[t]{2}{*}{ SKs number } & $\mathrm{S}$ & Bs & 19.3 & 18.0 & 22.0 & 19.0 & 1.3 & 0.4 & 6.8 & 13 \\
\hline & $\mathrm{S}$ & $\mathrm{Bu}$ & 24.5 & 22.0 & 27.0 & 25.0 & 1.1 & 0.3 & 4.6 & 14 \\
\hline \multirow[t]{2}{*}{ Ma number } & $\mathrm{S}$ & Bs & 1.0 & 1.0 & 1.0 & 1.0 & 0.0 & 0.0 & 0.0 & 7 \\
\hline & $\mathrm{S}$ & $\mathrm{Bu}$ & 2.0 & 2.0 & 2.0 & 2.0 & 0.0 & 0.0 & 0.0 & 21 \\
\hline Ma length & $\mathrm{S}$ & Bs & 26.1 & 23.0 & 36.0 & 25.0 & 4.5 & 1.7 & 17.3 & 7 \\
\hline Ma width & $\mathrm{S}$ & Bs & 10.3 & 9.0 & 11.0 & 10.5 & 0.8 & 0.3 & 7.9 & 6 \\
\hline \multirow{2}{*}{$\begin{array}{l}\text { Ma length (anterior) } \\
\qquad \quad \text { (posterior) }\end{array}$} & $\mathrm{S}$ & $\mathrm{Bu}$ & 25.9 & 13.0 & 50.0 & 23.5 & 10.9 & 2.6 & 42.0 & 18 \\
\hline & $\mathrm{S}$ & $\mathrm{Bu}$ & 21.8 & 12.0 & 36.0 & 20.0 & 6.1 & 1.4 & 27.9 & 19 \\
\hline \multirow{2}{*}{$\begin{array}{cl}\text { Ma width } & \text { (anterior) } \\
\prime \prime & \text { (posterior) }\end{array}$} & $\mathrm{S}$ & $\mathrm{Bu}$ & 16.3 & 8.5 & 28.0 & 14.5 & 5.6 & 1.3 & 34.4 & 18 \\
\hline & $\mathrm{S}$ & $\mathrm{Bu}$ & 16.6 & 10.0 & 30.0 & 15.0 & 4.9 & 1.1 & 29.7 & 19 \\
\hline \multirow[t]{2}{*}{ Mi number } & $\mathrm{s}$ & Bs & 5.4 & 4.0 & 7.0 & 5.0 & 1.1 & 0.5 & 21.1 & 5 \\
\hline & $\mathrm{S}$ & $\mathrm{Bu}$ & 6.6 & 4.0 & 9.0 & 7.0 & 1.7 & 0.4 & 25.8 & 16 \\
\hline \multirow[t]{2}{*}{ Mi diameter } & $\mathrm{s}$ & Bs & 1.8 & 1.5 & 2.5 & 1.5 & 0.4 & 0.2 & 24.8 & 5 \\
\hline & $\mathrm{S}$ & $\mathrm{Bu}$ & 2.5 & 2.0 & 3.0 & 2.5 & 0.4 & 0.1 & 15.4 & 14 \\
\hline \multirow[t]{2}{*}{ CV diameter } & $\mathrm{L}$ & Bs & 14.2 & 12.5 & 15.0 & 15.0 & 1.4 & 0.8 & 10.2 & 3 \\
\hline & $L$ & $\mathrm{Bu}$ & 21.7 & 17.5 & 25.0 & 22.5 & 3.1 & 1.0 & 14.1 & 9 \\
\hline
\end{tabular}

The abbreviations in the table are the same as in the text, the abbreviations not in text are as follows : Min.=minimum; Max.=maximum; Med.=median; $\mathrm{SD}=$ standard deviation; $\mathrm{SE}=$ standard error; $\mathrm{CV}=$ coefficient of variation in $\% ; n=$ population size; $L=l i v e ; S=$ stained. The unit of length and width is $\mu \mathrm{m}$. 

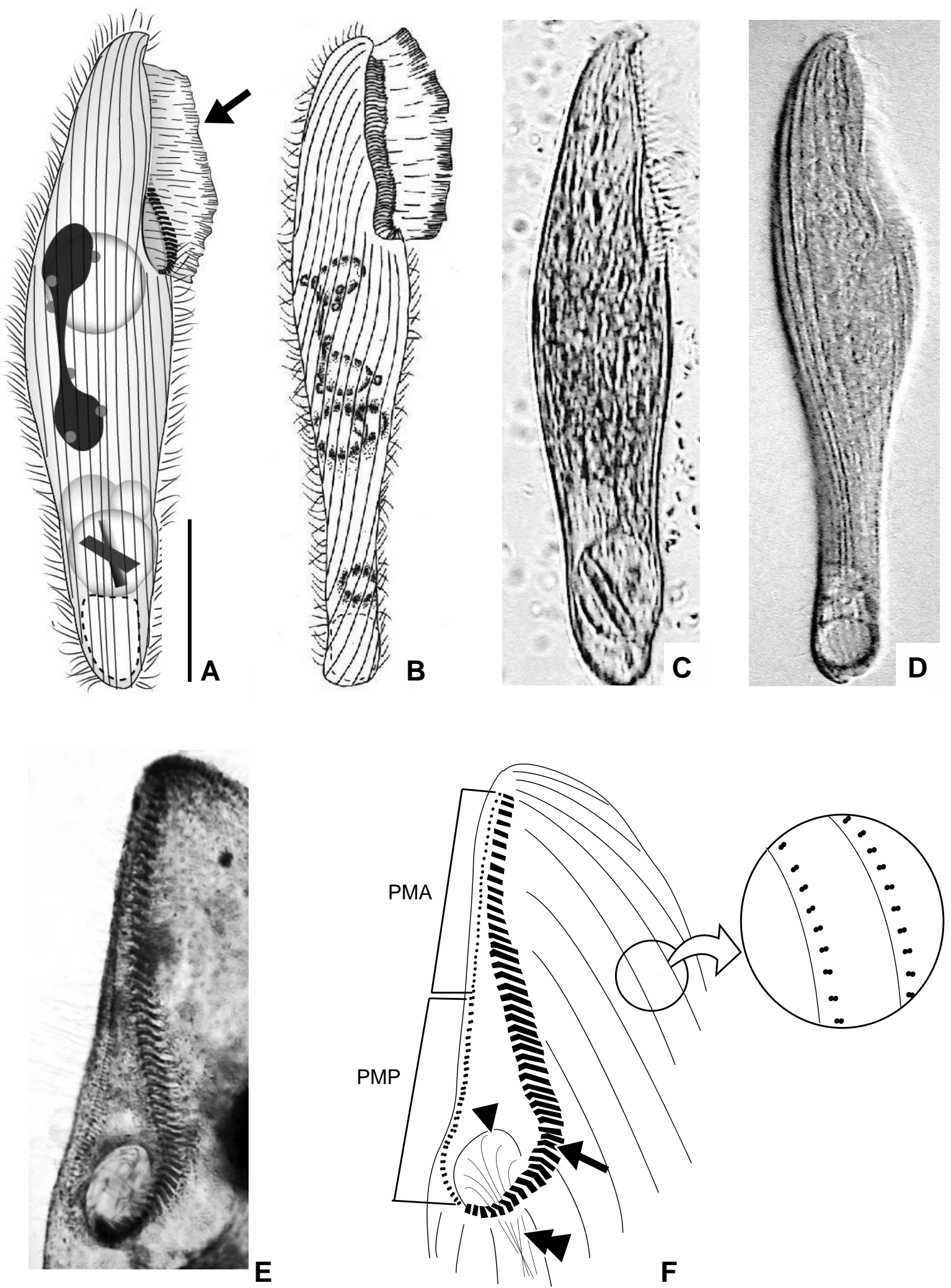

Fig. 1. Blepharisma undulans Stein, 1867. A-D, B. undulans body shape variation in live; very long and prominent PM (arrow in A). $\mathrm{E}$ and $\mathrm{F}$, oral apparatus (arrowhead indicates OG, double arrowhead indicates cytopharynx, arrow indicates AZM) and infraciliature. Scale bar $=50 \mu \mathrm{m}$. 

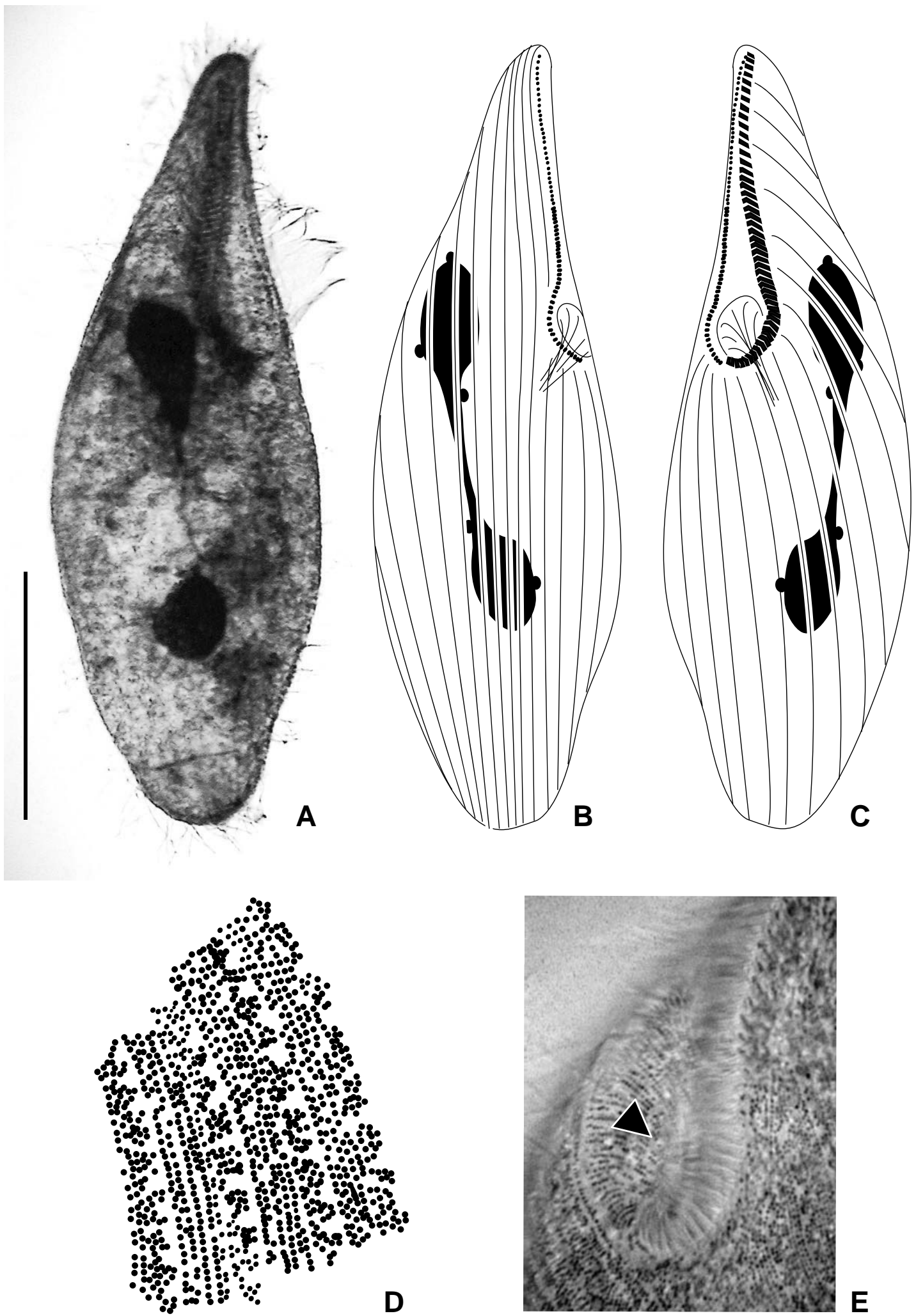

Fig. 2. Blepharisma undulans Stein, 1867. A, photograph after protargol impregnation. B and C, illustration of protargol impregnated specimens; $B$ right side, $C$ left side. $D$, subpellicular granules $(>1 \mu \mathrm{m})$ arrangement. $E$, oral groove (arrowhead) locates between AZM and PM. Scale bar $=50 \mu \mathrm{m}$. 
granules arranged parallel to body axis between ciliary rows, 2) 10-15 subpellicular granules gathered in each basal body neighborhood of somatic cirri (Fig. 2D). CV located in posterior body without collecting canals, $25 \mu \mathrm{m}$ in diameter. Near CV, food vacuoles emitting digested food or debris through pore like anus in body posterior. Oral apparatus consisting of AZM, OG (or peristomal field), cytopharynx (gullet) and very prominent PM. AZM 57.5-92.5 $\mu \mathrm{m}$ in length, covering $1 / 3$ part of body along left border of anterior, consisting of 47-56 AMs. Oral groove between AZM and PM terminating at gullet. Gullet leading into formation of food vacuole. PM consisting of PMA and PMP. PMA composed of a line of single basal bodies and PMP composed of paired basal bodies (Fig. 1E, F).

Ma consisting of two parts, one part located in anterior half and another located in posterior half of body; anterior Ma $13-50 \times 8.5-28 \mu \mathrm{m}$ and posterior Ma $12-36 \times 10-30 \mu \mathrm{m}$ in stained size. Ma connecting each other by a thin strand, each Ma shaped like ellipsoidal in stained. Four to nine spherical Mi locating close to the Ma surface and not embedded, diameter $2-3 \mu \mathrm{m}$ in stained.

Twenty two-27 SKs consisting of numerous cirri 6-7 $\mu \mathrm{m}$ in length. On the right side of cell, SKs running parallel to OG (Fig. 2B), while on the left side SKs running obliquely (Fig. 2C).

Distribution. Europe, Africa, America and Asia(China, India, Japan and Korea).

Remark. Blepharisma undulans has been redescribed many times since the first description by Stein in 1867. But $B$. undulans had many disagreements between the original description and other previous investigations. In 1954, Suzuki separated B. undulans Stein, 1867 as three subspecies under Blepharisma undulans (B. undulans americanus, B. undulans japonicus and B. undulans undulans) by Ma shape as well as performance in division. These three subspecies were elevated to the specific status as a species by Bhandary (1962).

The five species of Blepharisma have binodal Ma including B. undulans Stein, 1867, B. semifiliformis Isquith, 1966, B. tropicum Bhandary, 1962 and B. ichthyoides Gelei, 1933 and B. biancae Lepsi, 1948, while Blepharisma biancae is considered a nomen nudum because the original description is insufficient to characterize it (Giese, 1973). Blepharisma semifiliformis has bipartite Ma (generally one node) which is joined to an elongated node by a strand of varying thickness while $B$. undulans bimodal Ma connected with thin strand. The Ma of B. tropicum has two nodes connected by strand that is very thick as compared to $B$. undulans or is dumb-bell shaped. Blepharisma ichthyoides has short PM while long PM in B. undulans.

The characteristics of this population coincide with those of Japanese population except for body shape (Suzuki, 1954). They have a similar to body length, the number of SKs, the number and shape of Ma and Mi. The Japanese population had spindle shape and tapering towards and round extremities, while this population has a slight variation in shape of spindle to baseball bat.

\section{Blepharisma steini Kahl, 1932 (Fig. 3 and Table 1)}

Blepharisma steini Kahl, 1932, p. 444; Kahl, 1935, p. 839; Kudo, 1954, p. 803; Larsen and Nilsson, 1983, p. 93, Figs. 3, 4; Al-Rasheid, 2001, p. 142.

Blepharisma lateritium: Penard, 1922, p. 189.

Description. Body shape pyriform, anterior pole like a beak curved leftward; being starved, body compressed dorsoventrally, while being fed, body shaped droplet-wise and rounded posteriorly. Size $68-120 \times 35-50 \mu \mathrm{m}$ in vivo, length/width ratio about 2/1 (Fig. 3A-D). Body unflexible and pink to bright reddish in color. AMs fluttered actively, the cell moving with rotation in clockwise direction. Single large CV at body posterior without canals; $12.5-15 \mu \mathrm{m}$ in diameter. Mostly food vacuoles located posterior of body near CV, emitted food debris through pore like anus in body posterior.

Oral apparatus consisting of AZM, OG (or peristomal filed), PM and cytopharynx (or gullet). AZM located along left edge winding onto ventral surface and extended to $1 / 2$ $2 / 3$ of body length (50-75 $\mu \mathrm{m}$ in vivo), conspicuous PM on right of oral groove. OG positioned between AZM and PM, and terminated at gullet. Gullet leading into formation of food vacuole. AZM consisting 33-45 AMs.

One Ma compact, reniform or ovoid form, located in center of body (Fig. $3 \mathrm{~K}$ ); size 23-36 $\times 9-11 \mu \mathrm{m}$ (average $26 \times 10$ $\mu \mathrm{m})$ in stained. Four to 7 spherical Mi, each $1.5-2.5 \mu \mathrm{m}$ in diameter and attached to surface of Ma.

Somatic kineties $18-22$ in number total, on right side of organism, running parallel to body longitudinal axis (Fig. 3E, G), while on left side, running obliquely (Fig. 3F, H). Many pinkish subpellicular granules scattered within cortex between kineties (Fig. 3J). When organism touched or stressed during observation, granules easily disappeared.

Distribution. Europe, North America and Asia (Saudi Arabia, Korea).

Remark. The populations of Blepharisma steini have some variations in body length, for example, 150-200 $\mu \mathrm{m}$ in German population, 70-80 $\mu \mathrm{m}$ in American, 80-120 $\mu \mathrm{m}$ in French, and 68-120 $\mu \mathrm{m}$ in Korean (Penard, 1922; Kahl, 1932; the present study). The descriptions on this species were rare and poor because the size of this species is small and the cells are susceptible to burst up, so it is not easy to handle the specimens.

Blepharisma steini is very similar B. lateritium (Ehren- 



Fig. 3. Blepharisma steini Kahl, 1932. A, C and B, D, illustrations and photographs of $B$. steini in live. $E$ and $F$, illustrations of protargol impregnated specimens; $E$ right side, $F$ left side. G-I, photographs of protargol impregnated specimens $\mathrm{G}$ right side, $\mathrm{H}$ and I left side. J, subpellicular granules $(>1 \mu \mathrm{m})$ arrangement in live. $\mathrm{K}$, variation of Ma. Scale bars $=50 \mu \mathrm{m}$. 
berg, 1931) Kahl, 1932 and B. hyalinum Perty, 1852. Blepharisma steini is most similar to $B$. lateritium but different from it on the following points : (1) smaller than $B$. lateritium (68-120 vs. $130-200 \mu \mathrm{m})$; (2) number of $\mathrm{Mi}$ is more than in $B$. lateritium (4-7 vs. 1); (3) number of SKs is less than in $B$. lateritium (18-22 vs. 40); (4) number of subpellicular granules around each somatic cilia is $10-15$ in B. steini, but not mentoned in B. lateritium; (5) number of AMs is more than B. lateritium (33-45 vs. 30) (Kahl, 1932).

Blepharisma steini is also very similar to B. hyalinum, but different from it on the following points : (1) shape of posterior end is rounded (vs. pointed in B. hyalinum); (2) color of subpellicular granule is pinkish or bright reddish, while is colorless or transparent in B. hyalinum; (3) number of SKs is more than in B. hyalinum (18-22 vs. 15-18); (4) number of AMs is more in B. hyalinum (33-45 vs. 25) (Dragesco and Dragesco-Kernéis, 1986).

\section{ACKNOWLEDGEMENTS}

This work was supported by the 2007 Research Fund of University of Ulsan.

\section{REFERENCE}

Aescht, E. and W. Foissner, 1998. Divisional morphogenesis in Blepharisma americanum, B. undulans, and B. hyalinum (Ciliophora: Heterotrichida). Acta Protozool., 37: 71-92.

Al-Rasheid, K.A.S., 2001. New records of interstitial ciliates (Protozoa, Ciliophora) from the Saudi coasts of the Red Sea. Trop. Zool., 14: 133-156.

Bhandary, A.V., 1962. Taxonomy of genus Blepharisma with special reference to Blepharisma undulans. J. Protozool., 9: 435-442.

Curds, C.R., M.A. Gates and D.M. Roberts, 1983. British and other freshwater ciliated protozoa. Part II Ciliophora: Oligohymenophora and Polyhymenophora keys and notes for the identification of the free-living genera. Syn. British Fauna (N. S.), 23: 1-474.

Dragesco, J., 1970. Ciliés libres du Cameroun. Ann. Fac. Sci. Yaoundé (hors-série), pp. 88-90.

Dragesco, J. and A. Dragesco-Kernéis, 1986. Ciliés libres de l' Afrique intertropicale. Fauna Tropicale, 26: 369-371.
Foissner, W., 1992a. Estimating the species richness of soil protozoa using the "non-flooded petri dish method". In Lee, J.J. and A.T. Soldo, eds., Protocols in Protozoology (published by the society of Protozoologists), Allen Press, Kansas, p. B 10.1-B 10.2.

Foissner, W., 1992b. Protargol methods. In Lee, J.J. and A.T. Soldo, eds., Protocols in Protozoology (published by the society of Protozoologists), Allen Press, Kansas, p. C 6.1-C 6.8 .

Giese, A.C., 1973. Blepharisma, the biology of a light-senstive protozoan. Stanford University Press, pp. 1-366.

Hirshfield, H.I., I.R. Isquith and A.V. Bhandary, 1965. A proposed organization of the genus Blepharisma Perty and description of four new species. J. Protozool, 12: 136-144.

Isquith, I.R., A.J. Repak and H.I. Hirshfield, 1965. Blepharisma seculum, sp. nov., a member of the subgenus (Compactum). J. Protozool., 12: 615-618.

Kahl, A., 1932. Urtiere oder Protozoa I : Wimpertiere oder Ciliata (Infusoria) 3. Spirotricha. Tierwelt Dtl., 25: 442-447.

Kahl, A., 1935. Urtiere oder Protozoa I : Wimpertiere oder Ciliata (Infusoria) 4. Peritricha und Chonotricha. Tierwelt Dtl., 30: 651-886.

Kudo, R.R., 1954. Protozoology. 4th. Ed. Thomas, U.S.A., pp. 801-804.

Larsen, H.F. and J.R. Nilsson, 1983. Is Blepharisma hyalinum truly pigmented? J. Protozool., 30: 90-97.

Lüftenegger, G., W. Foissner and H. Adam, 1985. r-and Kselection in soil ciliates : a field and experimental approach. Oecologia (Berlin), 66: 574-579.

Lynn, D.H., 2008. The ciliated protozoa : characterization, classification, and guide to the literature. Springer, pp. 1-605.

Penard, E., 1922. Études sur les infusoires d'eau douce. Georg \& Cie, Genève, pp. 1-189.

Shin, M.K. and W. Kim, 1993. New records of three oxytrichid hypotrichs (Ciliophora: Hypotrichida: Oxytrichidae) from the Han river in Seoul, Korea. Korean J. Zool., 35: 223-230.

Stein, F., 1867. Der Organismus der Infusionsthiere nach eigenen Forschungen in systematischer Reihenfolge bearbeitet. Bd. II (Allgemeines u. Heterotricha). Leipzig., pp. 186-187.

Suzuki, S., 1954. Taxonomic studies on Blepharisma undulans Stein with special reference to macronuclear variation. J. Sci. Hiroshima. Univ. (ser. B. div. 1), 15: 205-220.

Wilbert, N., 1975. Eine vertesserte Technik der Protargolimpragnation für Ciliaten. Mikrokosmos, 64: 171-179.

Received February 11, 2009 Accepted March 8, 2009 